\title{
RAPD analysis of the genetic diversity of mango (Mangifera indica) germplasm in Brazil
}

\author{
I.G.B. Souza ${ }^{1}$, S.E.S. Valente ${ }^{1}$, F.B. Britto ${ }^{2}$, V.A.B. de Souza ${ }^{3}$ and \\ P.S.C. $\operatorname{Lima}^{3}$ \\ ${ }^{1}$ Programa em Genética e Melhoramento, \\ Universidade Federal do Piauí, Campus Agrícola da Socopo, \\ Teresina, PI, Brasil \\ ${ }^{2}$ Departamento de Ciências Naturais, \\ Universidade Federal do Piauí, Campus Cinobelina Elvas, \\ Planalto Horizonte, Bom Jesus, PI, Brasil \\ ${ }^{3}$ EMBRAPA Meio-Norte, Teresina, PI, Brasil
}

Corresponding author: P.S.C. Lima

E-mail: sarmanho@cpamn.embrapa.br/paulosarmanho@yahoo.com.br

Genet. Mol. Res. 10 (4): 3080-3089 (2011)

Received January 28, 2011

Accepted April 28, 2011

Published December 14, 2011

DOI http://dx.doi.org/10.4238/2011.December.14.1

\begin{abstract}
We evaluated genetic variability of mango (Mangifera indica) accessions maintained in the Active Germplasm Bank of Embrapa Meio-Norte in Teresina, Piauí, Brazil, using RAPDs. Among these accessions, 35 originated from plantings in Brazil, six from the USA and one from India. Genomic DNA, extracted from leaf material using a commercial purification kit, was subjected to PCR with the primers A01, A09, G03, G10, N05, and M16. Fifty-five polymorphic loci were identified, with mean of $9.16 \pm 3.31$ bands per primer and $100 \%$ polymorphism. Application of unweighted pair group method using arithmetic average cluster analysis demonstrated five genotypic groups among the accessions examined. The genotypes Rosa 41, Rosa 48 and Rosa 49 were highly similar (94\% similarity), whereas genotypes Sensation and Rosa 18 were the most divergent (only $7 \%$ similarity). The mango accessions were found to have considerable genetic variability,
\end{abstract}


demonstrating the importance of analyzing each genotype in a collection in order to efficiently maintain the germplasm collection.

Key words: Mangifera indica; Molecular markers; Genetic variability

\section{INTRODUCTION}

Mango (Mangifera indica L.) is one of main tropical fruits produced by Brazil. In 2008, mango was second only to melon in terms of export volume with some 133,724 t of the fresh fruit sold abroad, principally to the USA, the European Union and Asia (Instituto Brasileiro de Frutas, 2009). However, in order to expand Brazilian trade in this area, it is necessary to obtain first-class, disease-resistant cultivars that can be grown with increased productivity.

Although the north-eastern States of Bahia and Pernambuco are currently the largest producers of mango (Santos et al., 2008; Instituto Brasileiro de Frutas, 2009), the semiarid region of the State of Piauí exhibits significant potential for the culture of tropical fruits by virtue of its favorable ecological conditions (Dantas et al., 2009). However, the cultivation of mango in this area has only been attempted using cultivars that were not particularly suited to the conditions of the region (Silva, 2007), hence compromising overall productivity. It is crucial, therefore, to obtain new cultivars that are well adapted to the local conditions and less dependent on chemical flowering inducers. In order to achieve this objective, it is important to explore the biological diversity within the existing germplasm bank, as well as to introduce new varieties of mango with the purpose of increasing the gene pool available for crop improvement.

In the last 10 to 15 years, various molecular techniques have been successfully applied in determining the genotypic profiles of individuals and/or populations of numerous wild and cultivated plant species, and in identifying traits of interest within germplasm banks. Moreover, DNA markers, such as restriction fragment length polymorphism (RFLP), amplified fragment length polymorphism (AFLP) and randomly amplified polymorphic DNA (RAPD), offer significant advantages in comparison with morphological and isozyme markers because they can be readily obtained in large numbers, can provide greater discrimination of cultivars, and are unaffected by environmental factors (Borém, 1998). In this context, RAPD (Williams et al., 1990; Welsh and McClelland, 1990) has been employed extensively not only for the determination of genetic variability within plant taxonomic groups but also as an auxiliary tool in breeding programs and in obtaining genetic maps (Williams et al., 1990; Dunemann et al., 1994; Paillard et al., 1996). Additionally, the RAPD technique is fundamental in developing specific sequence-characterized amplified region (SCAR) markers for use in the assisted selection of crops (Marieschi et al., 2010; Wu et al., 2010).

There are numerous examples of the application of molecular markers in the analysis of the genetic diversity of mango (Viruel et al., 2005; Pandit et al., 2007; Santos et al., 2008; Singh and Bhat, 2009; Gálvez-López et al., 2009; Singh et al., 2010), several of which have employed the RAPD technique (Karihaloo et al., 2003; Ravishankar et al., 2004; Souza and Lima, 2004; Srivastava et al., 2004; Rajwana et al., 2008; Faleiro et al., 2009). RAPD markers have also been utilized in identifying genitors of open-pollinated mango hybrids generated by the Embrapa Cerrados Plant Improvement Program (Cordeiro et al., 2006a), and in determining the genetic origin of plantlets from polyembryonic mango seeds of cultivar Rosinha (Cor- 
deiro et al., 2006b). These researchers confirmed that the RAPD technique was very effective in detecting the differential traits targeted in each study.

The aim of the present study was to use RAPD markers to analyze the genetic variability among mango accessions in the Active Germplasm Bank of Embrapa Meio-Norte (Teresina, Piauí, Brazil), thus contributing to the maintenance and multiplication of this important collection and the improvement of mango culture in the semi-arid area of north-eastern Brazil.

\section{MATERIAL AND METHODS}

\section{Plant material and extraction of genomic DNA}

A total of 42 accessions maintained in the mango Active Germplasm Bank of Embrapa Meio-Norte were evaluated. The accessions comprised 18 samples of the Rosa variety and 14 regional varieties, all originating from Brazil, together with 10 improved cultivars, six of which originated from the USA, three from Brazil and one from India (Table 1).

\begin{tabular}{|c|c|c|c|c|c|}
\hline Accession & Origin & Group & Accession & Origin & Group \\
\hline Rosa 6 & Maranhão - BR & Rosa & Ananás & Maranhão - BR & Regional \\
\hline Rosa 7 & Maranhão - BR & Rosa & Xexéu & Piauí - BR & Regional \\
\hline Rosa 18 & Piaú - BR & Rosa & Caiana & Piauí - BR & Regional \\
\hline Rosa 48 & Piauí - BR & Rosa & D'Água & Piauí - BR & Regional \\
\hline Rosa 10 & Piauí - BR & Rosa & Jarbas & Piauí - BR & Regional \\
\hline Rosa 2 & Piauí - BR & Rosa & Carlota & Piauí - BR & Regional \\
\hline Rosa 14 & Piauí - BR & Rosa & Foice & Piauí - BR & Regional \\
\hline Rosa 24 & Piauí - BR & Rosa & Rainha & Piauí - BR & Regional \\
\hline Rosa 26 & Piauí - BR & Rosa & Peito-de-Moça & Piauí - BR & Regional \\
\hline Rosa 27 & Piauí - BR & Rosa & Lira & Piauí - BR & Regional \\
\hline Rosa 36 & Piauí - BR & Rosa & Piqui & Piauí - BR & Regional \\
\hline Rosa 41 & Piauí - BR & Rosa & Mallika & India & Improved \\
\hline Rosa 42 & Piauí - BR & Rosa & Edward & Florida - USA & Improved \\
\hline Rosa 19 & Piauí - BR & Rosa & Tommy Atkins & Florida - USA & Improved \\
\hline Rosa 20 & Piauí - BR & Rosa & Haden & Florida - USA & Improved \\
\hline Rosa 21 & Piauí - BR & Rosa & Sensation & Florida - USA & Improved \\
\hline Rosa 49 & Piauí - BR & Rosa & Kent & Florida - USA & Improved \\
\hline Rosa 50 & Piauí - BR & Rosa & Irwin & Florida - USA & Improved \\
\hline Favo-de-Mel & Bahia - BR & Regional & CPAC $10.44 / 86$ & Embrapa Cerrados & Improved \\
\hline Fafá & Ceará - BR & Regional & Alfa Embrapa 142 & Embrapa Cerrados & Improved \\
\hline Maça & Maranhão - BR & Regional & CPAC 294/94 & Embrapa Cerrados & Improved \\
\hline
\end{tabular}

Young healthy leaves from each of the accessions were collected into plastic bags, which were immediately hermetically sealed and packed in ice for transport to the laboratory. Samples were subsequently stored in the freezer at $-20^{\circ} \mathrm{C}$ until required for analysis. Leaves from each accession were separately macerated in liquid nitrogen, and DNA was extracted from $150 \mathrm{mg}$ samples with the aid of Gentra Puregene ${ }^{\mathbb{B}}$ DNA Purification Kits (Qiagen, Crawley, UK) using the protocol provided by the manufacturer. An aliquot of the extracted DNA was submitted to electrophoresis on a $0.8 \%$ agarose gel along with $100 \mathrm{ng} \lambda$ DNA, and quantified by comparison with the standard. Following quantification, a portion of the DNA sample was diluted in TE buffer (10 mM Tris and $0.1 \mathrm{mM}$ EDTA, $\mathrm{pH} 8.0)$ to a final concentration of $15 \mathrm{ng} / \mu \mathrm{L}$ for subsequent RAPD analysis. The remaining DNA stock samples were stored in the freezer at $-20^{\circ} \mathrm{C}$. 


\section{Amplification reactions}

In order to select the most polymorphic primers for RAPD analysis, DNA samples from the accessions Rosa 10 and Rosa 49 were amplified using 23 primers, namely, A01, A03, A05, A08, A09, A15, G03, G04, G06, G09, G10, G12, M05, M10, M11, M12, M14, M16, M20, N03, N05, N08, and N15 obtained from Eurofins MWG Operon (Huntsville, AL, USA). Elevated levels of polymorphism were detected with A01, AO9, G03, G10, N05, and M16, and these six primers were employed in the subsequent RAPD reactions.

Polymerase chain reactions (PCR) were carried out in a GeneAmp 2400 Thermal Cycler (Perkin-Elmer, Waltham, MA, USA). The reaction mixtures ( $20 \mu \mathrm{L}$ final volume) were prepared in $0.2-\mathrm{mL}$ microtubes and comprised $1 \mathrm{X}$ buffer solution (Invitrogen, Carlsbad, CA, USA), $1.0 \mathrm{mM} \mathrm{MgCl}, 800 \mu \mathrm{M}$ dNTP, 0.4 pmol primer, $1 \mathrm{U}$ Taq DNA polymerase and $1 \mu \mathrm{L}$ DNA template $(\sim 15 \mathrm{ng})$. The PCR temperature program involved an initial denaturation step of $1 \mathrm{~min}$ at $92^{\circ} \mathrm{C}$, followed by 40 cycles comprising denaturation for $1 \mathrm{~min}$ at $92^{\circ} \mathrm{C}$, annealing for $1 \mathrm{~min}$ at $35^{\circ} \mathrm{C}$ and extension for $2 \mathrm{~min}$ at $72^{\circ} \mathrm{C}$, and a final extension step of $5 \mathrm{~min}$ at $72^{\circ} \mathrm{C}$.

Amplicons were separated by electrophoresis on 1.4\% agarose gel in TBE buffer ( 8.9 $\mathrm{mM}$ Tris, $8.9 \mathrm{mM}$ boric acid and $0.2 \mathrm{mM}$ EDTA, $\mathrm{pH} 8.0$ ) at $80 \mathrm{~V}$ for $3.5 \mathrm{~h}$. An Invitrogen 100-bp DNA ladder was included as molecular weight marker. Gels were treated with $0.5 \mu \mathrm{L} /$ $\mathrm{mL}$ ethidium bromide for $40 \mathrm{~min}$, and bands were visualised and photographed under an UV transilluminator.

\section{Data analysis}

The number of polymorphic bands generated by each primer was determined by an initial visual examination of the gel photographs, taking into account the resolution and degree of amplification. Only bands of medium or strong intensity were included in the subsequent investigation. For RAPD analysis, the presence of the band was scored 1, whereas the absence of the band was coded 0 . The scored RAPD markers were converted into a binomial (0/1) matrix. Based on these matrices, the genetic similarities between mango accessions were determined using Jaccard coefficients, and a dendrogram was constructed by applying unweighted pair group method with arithmetic average (UPGMA) cluster analysis. Data were analyzed using the PAST software version 1.34 (Hammer et al., 2001).

Genetic structures were evaluated using Arlequin version 3.1 (Excoffier et al., 1992) and Hickory version 1.0.4 programs (Holsinger et al., 2002), following which the results of the two applications were compared. Analysis of molecular variance (AMOVA) was also performed to assess the genetic variability between three groups of mango samples.

\section{RESULTS}

PCR of mango DNA using the six selected primers generated a total of 55 polymorphic loci with $100 \%$ polymorphism (Table 2 ). The number of bands per primer varied between 6 (primers A01 and G10) and 14 (primer N05), with an average of $9.16 \pm 3.31$ bands per primer, while the size of the bands ranged between 344 and $4072 \mathrm{bp}$, approximately.

The coefficients of genetic similarity were in the range 0.07 (Sensation and Rosa 18 ) and 0.94 (Rosa 41, Rosa 48 and Rosa 49), with an average value of $0.36 \pm 0.18$. The 
Table 2. Polymorphic bands detected in the RAPD analysis of 42 mango accessions using 6 primers.

\begin{tabular}{llr}
\hline Primer & Sequence 5'-3' & Number of bands (loci) \\
\hline A01 & CAGGCCCTTC & 6 \\
A09 & GGGTAACGCC & 11 \\
G03 & GAGCCCTCCA & 11 \\
G10 & AGGGCCGTCT & 6 \\
N05 & ACTGAACGCC & 14 \\
M16 & GTAACCAGCC & 7 \\
Total & & 55 \\
\hline
\end{tabular}

dendrogram constructed using the UPGMA method applied to Jaccard similarity coefficients, revealed the genetic interrelationships amongst the 42 mango accessions and allowed five genotypic groups to be identified (Figure 1).

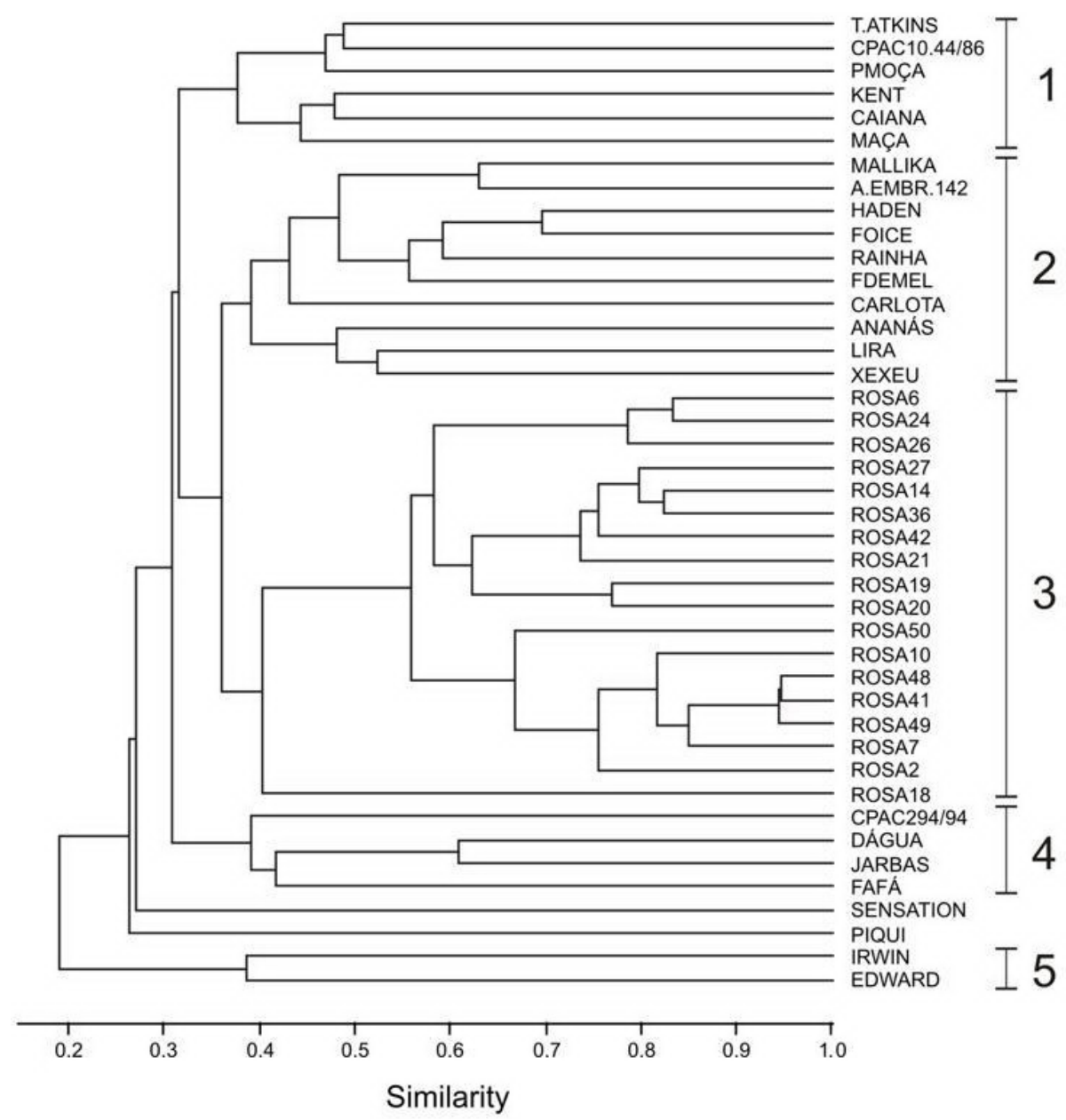

Figure 1. UPGMA dendrogram based on 55 RAPD polymorphic markers showing the relationship between 42 mango accessions maintained in the Active Germplasm Bank of Embrapa Meio-Norte (Teresina, Piauí, Brazil). 
AMOVA assessment of the genetic variability between the regional, improved and accessions of the variety Rosa revealed that $27.22 \%$ of the observed variation occurred among populations, whereas $72.80 \%$ occurred within the populations, suggesting a significant genetic divergence $(\mathrm{P}<0.0001)$ between the accessions (Table 3$)$. The three populations presented significant genetic variability $\left(\Phi_{\mathrm{ST}}=0.271 ; \mathrm{P}<0.0001\right.$; Table 3$)$. The $\theta_{\beta}$ value $(0.256)$, obtained via the Hickory program as an alternative estimate of Wright's $F_{\mathrm{ST}}$ statistic (Wright, 1978), indicated a high degree of genetic differentiation between the accessions. The endogamy index among the accessions (also obtained from the Hickory program) was determined as $0.6(-1<f<1)$.

Table 3. Analysis of molecular variance (AMOVA) performed on 42 mango accessions ${ }^{\mathrm{a}}$.
\begin{tabular}{lccccc}
\hline Source of variation & d.f. & Variance & Variation (\%) & Fixation index & P \\
\hline Among populations & 2 & 3.03681 & 27.22 & $\Phi_{\text {ST }}=0.27198$ & $<0.0001$ \\
Within populations & 39 & 8.12886 & 72.80 & & \\
\hline
\end{tabular}

${ }^{\mathrm{a}}$ The analysis was based on 55 loci (markers) amplified by RAPD using six primers. d.f. $=$ degrees of freedom.

\section{DISCUSSION}

The large percentage $(100 \%)$ of polymorphic bands detected in the present study clearly indicates that RAPD fragments are highly polymorphic and particularly informative in the estimation of genetic relationships. Similar levels of polymorphism associated with RAPD markers have been reported in earlier studies involving mango (Rahman et al., 2007; Anju et al., 2008; Rajwana et al., 2008). According to Faleiro et al. (2009), the number and percentage of polymorphism in RAPD fragments depend on the number and variability of the cultivars and/or accessions analyzed. Based on the results established herein, the variability present in the germplasm bank of Embrapa Meio-Norte must be considered significant.

The large amplitude (0.07-0.94; average 0.36$)$ of the genetic similarity coefficients established in the present study confirms the occurrence of considerable genetic variability among $M$. indica cultivars, as previously observed in other RAPD analyses (Karihaloo et al., 2003; Viruel et al., 2005; Rajwana et al., 2008). However, the variation amplitude presently determined was larger than that reported by Karihaloo and co-workers (2003) for Indian mango cultivars (range 0.32-0.75; average 0.56), and by Rajwana and co-workers (2008) for 25 mango cultivars developed in Pakistan (range 0.64-0.89; average 0.74). It is evident, therefore, that the mango germplasm maintained by Embrapa Meio-Norte exhibits an extremely high level of variability.

Considering the groupings of the accessions identified in the dendrogram shown in Figure 1 (cophenetic correlation $=0.88$ ), the inclusion of Tommy Atkins and Kent cultivars in group 1, together with the CPAC 10.44/86 hybrid, reflects the use of American cultivars as genitors in the Embrapa Cerrados Plant Improvement Program (Pinto et al., 2002a). It is possible, therefore, that the CPAC 10.44/86 hybrid represents a progeny of the Tommy Atkins cultivar. Group 1 also includes the regional variety Peito-de-Moça, Caiana and Maçã, although there is no logical genetic explanation for such an association. Possibly, the accessions studied resulted from a common genitor, since the genetic material derived from sexual propagation. In a similar manner, there is no logical explanation for the inclusion in group 4 of the CPAC 
294/94 hybrid along with the regional varieties D’Água, Jarbas and Fafá, which derive from a Philippine race. However, the possibility of an error in sampling or the misidentification of accession CPAC 294/94 cannot be ruled out.

In group 2, Mallika (Indian) and Alfa Embrapa 142 (Brazilian) cultivars form a subgroup, demonstrating the genetic relationship between these two accessions given that the former is one of the genitors of the latter (Pinto et al., 2002a). The sequential inclusion in this group of seven of the 12 regional accessions (all derived from a Philippine race) may indicate the occurrence of gene flow from the Haden cultivar, formerly the variety most commonly planted in the country, to the sexually propagated regional cultivars. According to Singh and Bhat (2009), gene flow between mango varieties from distant locations is not uncommon. The genetic distance established through the application of molecular markers may be associated with the crossing rate between interrelated species (Millan et al., 1996).

The genetic similarity coefficient of 0.70 between the variety Haden and Foice suggests the occurrence of an intense gene flow between these two varieties. According to some researchers (Pinto et al., 2002 a,b), Brazilian mango variety (including Rosa) descended from varieties containing genetic material from the Philippine race that were introduced by the Portuguese colonizers in the 16th century. The fruits of these cultivars were not only polyembryonic but also contained large amounts of fiber and were, hence, dissimilar from those of cultivars derived from the Indian race. This hypothesis of gene flow is corroborated by the fact that mango fruits from some regional varieties, including Fafá, Lira, Maçã, and Coité (although the last mentioned was not included in the present study), contain pulp with no fiber.

Group 3 comprised only accessions of the Rosa cultivar and, in this respect, is similar to the outcome of a study by Souza and Lima (2004) in which various accessions of Rosa were classified in a single group. However, the genetic variability presently reported for accessions of the Rosa cultivar is, on average, much greater than those observed in the Pakistani cultivar Chaunsa (Rajwana et al., 2008), which showed 81.2 to $88.6 \%$ similarity, and in six populations of the Columbian variety Hilacha (Díaz-Matallana et al., 2009). In the latter case, the genetic diversity within each population was equivalent to $95 \%$ of the total diversity of the six populations together.

The accession Rosa 18 presented the smallest coefficient of genetic similarity $(0.40)$ within group 3 indicating that, although the accessions of this cultivar were grouped together, significant genetic variability remained within the group and could be exploited in the genetic improvement of the variety. Such enhancement would be advantageous since this group includes the oldest and most common of Brazilian mango cultivars (Pinto et al., 2002b) and is, hence, greatly appreciated by the national market, particularly in north-eastern Brazil. The accessions Rosa 41, Rosa 48 and Rosa 49 presented the highest genetic similarity (0.94) and yet these materials can contribute to breeding programs even though their variability is low.

Group 5 consisted of two American cultivars, namely Edward and Irwin, which were clearly genetically distant from the other American accessions examined. Moreover, there was considerable variability between these two accessions where the genetic similarity coefficient was equivalent to $38 \%$. Interestingly, two other American cultivars, namely, Tommy Atkins and Sensation also exhibited 33\% similarity.

According to AMOVA, the greatest genetic variability (72.80\%) resulted from differentiation of accessions within the three mango populations, namely, the improved, regional and Rosa variety. However, a large variability was also detected within the populations, dem- 
onstrating the high level of genetic variability of the mango germplasm investigated $\left(\Phi_{\mathrm{ST}}=\right.$ 0.271 ; Table 3). Such divergence is to be expected in a preferentially allogamous species, such as mango, in which the majority of cultivars may have derived by targeted selection amongst natural growing shoots.

The parameter $\Phi_{\mathrm{ST}}$ is a measure of the degree of genetic differentiation among populations. Considering the statistical definition of this parameter, it may be presumed that such differentiation is small when $\Phi_{\mathrm{ST}}$ values are in the range $0-0.05$, moderate for values $0.05-0.15$, high for values $0.15-0.25$, and very high for values $>0.25$ (Hartl and Clark, 1997; Wright, 1978). On this basis, the $\Phi_{\mathrm{ST}}$ value of 0.271 obtained from the Arlequin program indicated a very high genetic diversity amongst the mango accessions investigated. The value of $\theta_{\beta}$ obtained from the Hickory program was also high and this, taken together with the $\Phi_{\mathrm{ST}}$ value, confirmed that the RAPD markers were efficient and represent a potentially value tool in plant improvement programs.

The high level of endogamy among the accessions (revealed by the index value of 0.6) probably resulted from crossings between close genotypes, particularly among the Rosa accessions. While the domestication and genetic improvement of plant species aim to incorporate desirable traits, such processes may lead to the loss of genetic variability with consequential negative effects on production. For this reason, surveillance of the genetic variability within mango germplasm is important to maintain the successful cultivation of mango.

The specific characteristics of RAPD markers, such as randomness, dominant nature, and possibility of co-migrating bands representing non-homologous fragments, may limit their value in genetic studies of populations (Lynch and Milligan, 1994). However, RAPD analysis can be used effectively for an initial evaluation of the degree of intraspecific genetic variation, particularly with regard to the genetic diversity of tropical arboreous species about which comparatively little is known. The application of RAPD in mango studies has produced valuable information regarding the integrity of the species, the identification of errors in germplasm banks and regional compartmentalization of genetic diversity.

\section{CONCLUSIONS}

RAPD analysis has been shown to be a useful technique for providing information concerning the degree of polymorphism and diversity of mango, as well as for characterizing the germplasm. The populations of mango preserved in the Active Germplasm Bank of Embrapa Meio-Norte present a considerable level of genetic differentiation and high genetic variability, and hence may be employed in improvement programs.

\section{REFERENCES}

Anju B, Navin S, Rajan S and Chandra RS (2008). Genetic diversity and discrimination of mango accessions using RAPD and ISSR markers. Indian J. Horticult. 65: 377-382.

Borém A (1998). Melhoramento de Plantas. 22 $2^{\mathrm{a}}$ ed. Universidade Federal de Viçosa, Viçosa.

Cordeiro MCR, Pinto ACQ, Ramos VHV, Faleiro FG, et al. (2006a). RAPD markers utilization and other parameters in the determination of mango hybrids genitors. Rev. Bras. Frutic. 28: 164-167.

Cordeiro MCR, Pinto ACQ, Ramos VHV, Faleiro FG, et al. (2006b). Identificação da origem genética de plântulas em sementes poliembriônicas de mangueira (Mangifera indica, 1.) cv. Rosinha por meio de marcadores RAPD. Rev. Bras. Frutic. 28: 454-457.

Dantas JLL, Dantas ACVL and Coelho YS (2009). Fruticultura Brasileira: Realidade e Perspectivas. In: Fruticultura 
Tropical: Espécies Regionais e Exóticas. Embrapa Informação Tecnológica, Brasília, 17-32.

Díaz-Matallana M, Schuler-García I, Ruiz-García M and Hodson-de-Jaramillo E (2009). Analysis of diversity among six populations of Colombian mango (Mangifera indica L. cv. Hilacha) using RAPDs markers. Electron. J. Biotechnol. 12: 1-8.

Dunemann F, Kahnau R and Schmidt H (1994). Genetic relationships in Malus evaluated by RAPD "fingerprinting" of cultivars and wild species. Plant Breed. 113: 150-159.

Excoffier L, Smouse PE and Quattro JM (1992). Analysis of molecular variance inferred from metric distances among DNA haplotypes: application to human mitochondrial DNA restriction data. Genetics 131: 479-491.

Faleiro FG, Pinto ACQ, Cordeiro MCR, Andrade SEM, et al. (2009). Genetic variability of mango cultivars developed by Embrapa Cerrados breeding program using RAPD markers. Acta Horticult. 820: 177-182.

Gálvez-López D, Hernández-Delgado S, González-Paz M, Becerra-Leor EN, et al. (2009). Genetic analysis of mango landraces from Mexico based on molecular markers. Plant Genet. Resour. 7: 244-251.

Hammer O, Harper DAT and Ryan PD (2001). PAST: paleontological statistics software package for education and data analysis. Paleontol. Electron. 4: 1-9.

Hartl DL and Clark AG (1997). Principles of Population Genetics. 3rd edn. Sinauer Associates, Sunderland.

Holsinger KE, Lewis PO and Dey DK (2002). A Bayesian approach to inferring population structure from dominant markers. Mol. Ecol. 11: 1157-1164.

Instituto Brasileiro de Frutas (2009). Comparativo das Exportações Brasileiras de Frutas Frescas. Available at [http:// www.ibraf.org.br/estatisticas/Exportação/ComparativoExportacoesBrasileiras2008-2007.pdf]. Accessed October 27, 2009.

Karihaloo JL, Dwivedi YK, Archak S and Gaikwad AB (2003). Analysis of genetic diversity of Indian mango cultivars using RAPD markers. J. Hortic. Sci. Biotechnol. 78: 285-289.

Lynch M and Milligan BG (1994). Analysis of population genetic structure with RAPD markers. Mol. Ecol. 3: 91-99.

Marieschi M, Torelli A, Poli F, Bianchi A, et al. (2010). Quality control of commercial Mediterranean oregano: Development of SCAR markers for the detection of the adulterants Cistus incanus L., Rubus caesius L. and Rhus coriaria L. Food Control. 21: 998-1003.

Millan T, Osuna F, Cobos S, Torres AM, et al. (1996). Using RAPDs to study phylogenetic relationships in Rosa. Theor. Appl. Genet. 92: 273-277.

Paillard M, Lashermes P and Pétrard V (1996). Construction of a molecular linkage map in coffee. Theor. Appl. Genet. 93: 41-47.

Pandit SS, Mitra S, Giri AP, Pujari KH, et al. (2007). Genetic diversity analysis of mango cultivars using inter simple sequence repeat markers. Curr. Sci. 93: 1135-1141.

Pinto ACQ, Costa JG and Santos CAF (2002a). Principais Variedades. In: A Cultura da Mangueira (Genú PJC and Pinto ACQ, eds.). Embrapa Informação Tecnológica, Brasília, 95-116.

Pinto ACQ, Souza VAB, Rossetto CJ and Ferreira FR (2002b). Melhoramento Genético. In: A Cultura da Mangueira (Genú PJC and Pinto ACQ, eds.). Embrapa Informação Tecnológica, Brasília, 53-92.

Rahman ML, Rabbani MG, Siddique MNA, Rahman MA, et al. (2007). Molecular characterization of 28 mango germplasm using RAPD. Plant Tissue Cult. Biotechnol. 17: 71-77.

Rajwana IA, Tabbasam N, Malik AU, Malik AS, et al. (2008). Assessment of genetic diversity among mango (Mangifera indica L.) genotypes using RAPD markers. Sci. Horticult. 117: 297-301.

Ravishankar KV, Chandrashekara P, Sreedhara SA and Dinesh MR (2004). Diverse genetic bases of Indian polyembryonic and monoembryonic mango (Mangifera indica L.) cultivars. Curr. Sci. 87: 870-871.

Santos CAF, Lima-Neto FP, Rodrigues MA and Costa JG (2008). Similaridade genética de acessos de mangueira de diferentes origens geográficas avaliadas por marcadores AFLP. Rev. Bras. Frutic. 30: 736-740.

Silva JIO (2007). Uso de Reguladores de Crescimento na Indução Floral de Mangueiras da Variedade Tommy Atkins, Master's thesis, Universidade Federal do Piauí, Teresina.

Singh S and Bhat KV (2009). Molecular characterization and analysis of geographical differentiation of Indian mango (Mangifera indica L.) germplasm. Acta Horticult. 839: 599-606.

Singh S, Gaikwad AB and Karihaloo JL (2010). Morphological and molecular analysis of intracultivar variation in Indian mango (Mangifera indica L.) cultivars. Acta Horticult. 29: 205-212.

Souza VAB and Lima PSC (2004). Genetic variability in mango genotypes detected by RAPD markers. Acta Horticult. 645: 303-310.

Srivastava AP, Chandra R and Ranade SA (2004). Applicability of PCR based molecular markers for parentage analysis of mango (Mangifera indica L.) hybrids. Indian J. Genet. Plant Breed. 64: 275-280.

Viruel MA, Escribano P, Barbieri M, Ferri M, et al. (2005). Fingerprinting, embryo type and geographic differentiation in mango (Mangifera indica L. Anacardiaceae) with microsatellites. Mol. Breed. 15: 338-393. 
Welsh J and McClelland M (1990). Fingerprinting genomes using PCR with arbitrary primers. Nucleic Acids Res. 18: 7213-7218.

Williams JG, Kubelik AR, Livak KJ, Rafalski JA, et al. (1990). DNA polymorphisms amplified by arbitrary primers are useful as genetic markers. Nucleic Acids Res. 18: 6531-6535.

Wright S (1978). Evolution and the Genetics of Population: Variability Within and Among Natural Populations. University of Chicago Press, Chicago.

Wu X, Li H, Zhao W, Fu L, et al. (2010). SCAR makers and multiplex PCR-based rapid molecular typing of Lentinula edodes strains. Curr. Microbiol. 61: 381-389. 